\title{
Вибір тактики лікування ускладнених форм жовчнокам'яної хвороби у похилому і старечому віці
}

\author{
O. YE. KANIKOVSKYI, YA. V. KARYI, YU. V. BABIYCHUK \\ M. I. Pyrohov Vinnytsia National Medical University
}

\section{CHOICE OF TREATMENT TACTICS OF COMPLICATED FORMS OF CHOLELITHIASIS IN ELDERLY AND SENILE AGE}

\begin{abstract}
У статті представлено результати хірургічного лікування 380 хворих на ускладнені форми жовчнокам'яної хвороби (ЖКХ). Ускладнений перебіг гострого калькульозного холециститу спостерігався у 149 (39,2 \%) пацієнтів, хронічного - у 136 (35,8 \%). Патологію жовчних проток діагностовано у 95 (25,0\%) хворих. Малоінвазивні операційні втручання проведено у 320 (84,2 \%) пацієнтів, відкриті - у 60 (15,8 \%). Ускладнення після малоінвазивних втручань спостерігали у $4(1,2 \%)$ хворих, після відкритих - у 6 (10,0 \%). Померли 2 (3,3 \%) пацієнти. За результатами проведеного дослідження показано, що застосування малоінвазивних втручань при ускладнених формах ЖКХ у хворих похилого і старечого віку є пріоритетним.

The article adduces the results of surgical treatment of 380 patients with complicated forms of the gallstone disease (GSD). The complicated course of an acute calculous cholecystitis was observed in $149(39.2 \%)$ patients, and chronic one was in 136 $(35.8 \%)$ patients. Bile duct pathology was diagnosed in $95(25.0 \%)$ patients. Minimally invasive surgical interferences were performed in $320(84.2 \%)$ patients, and open surgical interferences were performed in 60 (15.8 \%) patients. Complications following after minimally invasive surgical interferences were observed in $4(1.2 \%)$ cases, and after open surgical interferences were in $6(10.0 \%)$ cases. $2(3.3 \%)$ patients died. The results of the study demonstrated that minimally invasive surgical interferences in complicated forms of the GSD in elderly and senile patients are with the highest priority.
\end{abstract}

Постановка проблеми і аналіз останніх досліджень та публікацій. Захворюваність на ЖКХ протягом останніх десятиліть має тенденцію до зростання, особливо її ускладнені форми [1]. Серед хворих на ускладнену ЖКХ 65-70 \% становлять особипохилого і старечого віку [2]. На сьогодні поряд з традиційними операціями впроваджуються малоінвазивні втручання, спрямовані на корекцію ускладненої біліарної патології [4]. Розвиток малоінвазивних технологій дозволив розширити показання і можливість виконання операційних втручань у хворих похилого та старечого віку з ускладненим перебігом ЖКХ [5]. Однак залишаються невизначеними критерії вибору малоінвазивних втручань при ускладнених формах ЖКХ у цій віковій групі [3].

Мета роботи: визначити ефективність малоінвазивних та відкритих операційних втручань при лікуванні ускладнених форм ЖКХ у похилому і старечому віці.

Матеріали і методи. Протягом 2002-2015 рр. у хірургічній клініці медичного факультету № 2 Вінницького національного медичного університету імені М. І. Пирогова лікувалися 380 хворих на ускладнені форми ЖКХ. Чоловіків було 115 (30,3 \%), жінок - 265 (69,7 \%). Вік хворих - від 60 до 90 років. Тривалість захворювання від 1 міс. до 28 років.

Ускладнений перебіг гострого калькульозного холециститу спостерігали у 149 (39,2 \%) пацієнтів: емпієму жовчного міхура - у 59 (15,5 \%), паравезикальний інфільтрат - у 68 (17,9 \%), паравезикальний абсцес - у 17 (4,3 \%) і жовчний перитоніт - у 5 (1,3 \%). Ускладнений перебіг хронічного холециститу констатовано у 136 (35,8 \%) хворих: склеротичний жовчний міхур - у 46 (12,1 \%), водянку жовчного міхура - у 32 (8,4 \%), надмірний злуковий процес - у 40 (10,5 \%), синдром Міриззі - у 10 (2,6 \%) та біліодигестивні нориці - у 8 (2,1 \%). Патологію жовчних проток діагностовано у 95 (25,0\%) хворих: холедохолітіаз - 72 (18,9 \%), стриктуру спільної жовчної протоки (СЖП) - у 4 (1,0 \%) і стенозувальний папіліт - у 19 (5,0 \%). Обтураційну жовтяницю (ОЖ) констатовано у 87 (22,9\%) хворих. Ї̈̈ причиною були: холедохолітіаз - у 58 (15,3 \%), синдром Міриззі - у 5 (1,3\%), стриктура СЖП-у 4(1,0\%), стенозувальний папіліт - у 16 (4,2\%), хронічний індуративний панкреатит - у 3 (0,8 \%) i виразка дванадцятипалої кишки (ДПК) з пенетрацією в гепатодуоденальну зв’язку - в 1 (0,2 \%) хворого. 
Скринінг-методом діагностики патології жовчного міхура і жовчних проток було трансабдомінальне ультразвукове дослідження (ТУЗД), яке проводили всім хворим. Ехографічне дослідження виконували на діагностичному апараті Lodgiq-500 PRO Series GE. У хворих на ОЖ здійснювали фіброгастродуоденоскопію (ФГДС) за допомогою фіброгастродуоденоскопа Pentax-290V. Для прямого контрастування жовчних проток проводили ендоскопічну ретроградну панкреатохолангіографію (ЕРПХГ) 3 використанням $30 \%$ водорозчинного контрасту об'ємом 20-40 мл та 5-10 мл для контрастування головної протоки підшлункової залози. Для контрастування жовчних проток під час операції виконували інтраопераційну холангіографію (IOXГ) шляхом введення 10-20 мл 30 \% контрастної речовини через куксу міхурової протоки або при пункції жовчних проток. При неможливості канюляції великого сосочка (ВС) ДПК проводили ендоскопічне ультразвукове дослідження (ЕУЗД) за допомогою діагностичного апарата Olympus Exera EU M 60 та магнітнорезонансну томографію (МРТ) на комп’ютерному томографі Somatom-CR.

Результати досліджень та їх обговорення. ТУЗД було інформативним при виявленні холецистохоледохолітіазу та при первинній діагностиці біліарної гіпертензії. Інформативність ТУЗД у діагностиці ускладнених форм ЖКХ склала 256 (67,4 \%). У 25 (6,6 \%) випадках незадовільні результати ТУЗД були зумовлені: вираженим метеоризмом - 6 (1,6 \%), ожирінням - 5 (1,3\%), злуковим процесом - 6 (1,6 \%), наявністю множинних дрібних конкрементів (менше 3 мм) у термінальному відділі СЖП - 5 (1,3 \%), аерохолією - 3 (0,8 \%). У таких випадках застосовано ЕУЗД. Також ЕУЗД дозволяло об’єктивно оцінити співвідношення діаметрів конкремента і термінального відділу СЖП.

У 87 (22,9\%) хворих на ОЖ ФГДС дала можливість оцінити форму і розміри ВС ДПК, характер та кількість жовчі, яка виділялась, а також визначитися 3 можливістю подальшого виконання ЕРПХГ. ФГДС також застосовували для проведення диференційної діагностики ОЖ між вклиненим конкрементом у дистальному відділі СЖП і патологією ВС ДПК.

Для контрастування жовчних проток проведено ЕРПХГ у 59 (15,5 \%) хворих. Діагностовано холедохолітіаз у 38(10,0\%) пацієнтів, стенозувальний папіліт - у 16 (4,2 \%) і резидуальний холедохолітіаз -у 5 (1,3\%). Однак, виконати ЕРПХГ не було можливості у 13 (3,4 \%) хворих: при наявності конкремента в ампулі ВС ДПК у 5 (1,3 \%), парафатеріального дивертикула - у 4 (1,0 \%), раку ВС ДПК - у 2 (0,5 \%) і алергії на контрастну речовину - у 2 (0,5 \%). У даних випадках застосовано ЕУЗД, яке $є$ менш інвазивним методом діагностики протокової патології порівняно з ЕРПХГ. Ускладнення після ЕРПХГ спостерігали у
5 (1,3 \%) хворих: гострий панкреатит - у 3 (0,8 \%), гострий холангіт - у 1 (0,3 \%) і кровотечу з ВС ДПК - у 1 (0,3 \%) при поєднанні ЕРПХГ з ендоскопічною папілосфінктеротомією (ЕПСТ).

IOXГ проведено 38 (10,0 \%) пацієнтам шляхом введення контрасту в жовчні протоки через куксу міхурової протоки у 17 (4,5 \%) і при пункції жовчних проток у 10 (2,6 \%) осіб при виконанні відкритої холецистектомії (ВХЕ). Під час проведення лапароскопічної холецистектомії (ЛХЕ) IOXГ здійснювали шляхом катетеризації міхурової протоки в 11 (2,9 \%) хворих. Діагностовано холедохолітіаз у 16 (4,2 \%), синдром Міриззі - у 10 (2,6 \%), стриктуру СЖП - у 4 (1,0 \%) і біліодигестивні нориці - у 8 (2,1 \%). У 3 (0,8 \%) пацієнтів спостерігали ускладнення після введення контрасту в жовчні протоки: гострий панкреатит у 2 (0,5 \%) і гострий холангіт у 1 (0,3 \%).

МРТ для діагностики холедохолітіазу проведено в разі неможливості виконання ЕРПХГ і ЕУЗД у 4 (1,0 \%) випадках після резекції шлунка за Більрот II. Також МРТ застосовано для визначення протокової гіпертензії при хронічному індуративному панкреатиті у 3 ( $0,8 \%)$ хворих.

При ускладненому перебігу гострого калькульозного холециститу проведено малоінвазивні втручання у 135 (35,5 \%) випадках. Під час ЛХЕ у 56 (14,7 \%) хворих через наявність щільного паравезикального інфільтрату захопити кишеню Hartmann і провести латеральну тракцію було неможливо. У таких випадках розпочинали мобілізацію жовчного міхура з латеральної стінки на медіальну в проекції шийки жовчного міхура (патент України на корисну модель № 77985). У 17 (4,5%) хворих при наявності холедохолітіазу застосовано двохетапну тактику (ЛХЕ з подальшою ЕПСТ у ранньому післяопераційному періоді). У 7 (1,8%) пацієнтів після ЕПСТ відбулось самостійне відходження конкрементів діаметром 5-10 мм. Літоекстракцію корзинкою Дорміа (Olympus FG-22Q) виконано у 5 (1,3 \%) хворих. При розмірах конкрементів 10-20 мм проводили механічну літотрипсію за допомогою літотриптораOlympusBML-201Qy5(1,3\%)пацієнтів. Занаявності ОЖ виконували повторні дозованіЕПСТ, оскільки швидка біліарна декомпресія призводила до прогресування печінкової недостатності. У 8 (2,1%) хворих при наявності гнійного холангіту здійснено ЕПСТ і назобіліарне дренування, яке дало змогу провести етапну декомпресію та санацію жовчних проток. Одноетапні операції (ЛХЕ з наступним втручанням на жовчних протоках) проводили за наявності нещільного паравезикального інфільтрату в 11 (2,9 \%) пацієнтів, коли без технічних труднощів виділялась СЖП. У 4 (1,0 \%) хворих з конкрементами СЖП до 5 мм проведено ЛХЕ і літоекстракцію корзинкою Дорміа через куксу міхурової протоки. ЛХЕ зі зовнішнім дренуванням СЖП здійснено у 7 (1,8 \%) хворих при синдромі Міриззі I типу. 
При ускладненому перебігу хронічного калькульозного холециститу проведено малоінвазивні операції у 185 (48,7 \%) хворих. У 46 (12,1%) пацієнтів через склеротичні зміни стінок жовчного міхура спостерігали високе розташування міхурової протоки й артерії. У таких випадках мобілізували жовчний міхур з його латеральної стінки на медіальну в проекції кишені Hartmann (патент України на корисну модель № 77985). Надмірний злуковий процес у над- та підпечінковому просторах у 40 (10,5 \%) хворих утруднював проведення ЛХЕ. Розсічення злук проводили на відстань, необхідну для мобілізації жовчного міхура і препарування міхурової протоки та артеріі. У 22 (5,8 \%) пацієнтів з холедохолітіазом i у 16 (4,2 \%) зі стенозувальним папілітом, які були діагностовані до операції, застосовано двохетапну тактику (ЕПСТ із подальшою ЛХЕ). Проміжок часу між ЕПСТ та ЛХЕ був мінімальним (2-3 доби), що зменшувало ризик міграції конкрементів 3 жовчного міхура у СЖП. Одноетапні втручання (ЛХЕ з цистиколітотомією) проводили за відсутності склеротичного жовчного міхура і надмірного злукового процесу в 6 (1,7 \%) хворих з холедохолітіазом.

Одноетапні відкриті операційні втручання на жовчних протоках проведено у 60 (15,8 \%) пацієнтів. У 16 (4,2 \%) хворих з холедохолітіазом виконано холедохолітотомію через наявність конкрементів більше 20 мм, які не вдалось видалити через транспапілярний доступ. Для проведення літоекстракції з подальшою дозованою декомпресією жовчних проток у післяопераційному періоді застосовували зонд-обтуратор позапечінкових жовчних проток (патент на винахід № 104826). Після холецистектомії зонд-обтуратор вводили через куксу міхурової протоки у СЖП для проведення літоекстракції. Після ліквідації холедохолітіазу та контролю повноти холедохолітотомії повторно заводили зонд у СЖП. У післяопераційному періоді поступово зменшували об’єм балона-обтуратора, шо давало можливість проводити дозовану декомпресію жовчних проток. При непрохідності термінального відділу СЖП у 12 (3,2 \%) хворих з холедохолітіазом i y $3(0,8 \%)$ хронічним індуративним панкреати-

\section{СПИСОК ЛІТЕРАТУРИ}

1. Гойда С. М. Тенденції поширеності жовчнокам'яної хвороби серед населення України / С. М. Гойда // Український медичний часопис. - 2011. - № 4. - С. 112-113.

2. Грубник В. В. Особенности лапароскопических вмешательств у больных с калькулёзным холециститом на фоне цирроза печени / В. В. Грубник, А. Л. Ковальчук, А. С. Дюжев // Клінічна хірургія. - 2007. - № 1. - С. 16-19.

3. Ковальчук О. Л. Прогнозування ускладнень при виконанні лапароскопічної холецистектомії у хворих на цироз печінки / О. Л. Ковальчук, В. В. Грубник // Шпитальна хірургія. - 2010. том сформовано холедоходуоденоанастомоз за розробленою антирефлюксною методикою (патент на винахід № 85986). ВХЕ з гепатикоєюностомією на виключеній за Roux петлі порожньої кишки проведено у 7 (1,8 \%) пацієнтів: в 4 (1,0 \%) зі стриктурою СЖП і у 3 (0,8 \%) - із синдромом Міриззі II типу. У 8 (2,1 \%) пацієнтів з біліодигестивними норицями виконано ВХЕ й ушивання дефекту кишки. Санацію та дренування черевної порожнини проведено за наявності паравезикального абсцесу в 9 (2,3 \%) i жовчного перитоніту в 5 (1,3%) хворих.

Ускладнення після 320 малоінвазивних втручань спостерігали у 4 (1,2 \%) пацієнтів: неспроможність кукси міхурової протоки - в 1 (0,3 \%), гострий панкреатит - у 2 (0,6 \%) і кровотечу з ВС ДПК після ЕПСТ - в 1 (0,3 \%). Летальних випадків не було. Ускладнення після 60 відкритих операційних втручань діагностували у 6 (10,0 \%) хворих: неспроможність кукси міхурової протоки - в 1 (1,7 \%), жовчовитікання із СЖП - у 2 (3,3 \%), неспроможність біліодигестивного анастомозу - в 2 (3,3 \%) та нагноєння післяопераційної рани - у 1 (1,7 \%). Померли 2 (3,3 \%) пацієнти після відкритих операцій, де причиною смерті став обширний інфаркт міокарда - 1 (1,7 \%) та масивна тромбоемболія легеневої артерії $-1(1,7 \%)$.

Висновки. 1. Застосування малоінвазивних операційних втручань при ускладнених формах ЖКХ у хворих похилого і старечого віку є пріоритетним, що дозволяє знизити частоту післяопераційних ускладнень на 8,8 \% та післяопераційну летальність на 3,3 \%.

2. ТУЗД є інформативним методом первинної діагностики біліарної гіпертензії. Для об’єктивної оцінки співвідношення діаметрів конкремента i термінального відділу СЖП доцільно застосовувати ЕУЗД. Порівняно з ЕРПХГ ЕУЗД є менш інвазивним методом діагностики патології жовчних проток, оскільки не викликає ускладнень, пов'язаних із введенням контрасту.

3. Проведення літоекстракції доцільно доповнювати методом дозованої декомпресії жовчних проток у післяопераційному періоді.
- № 3. - С. 8-12.

4. Кондратенко П. Г. Лапароскопическая холецистэктомия после острого гнойного холангита желчнокаменной этиологии: индивидуализированный либо протокольный подход?/ П. Г. Кондратенко, Ю. А. Царульков // Український журнал хірургіï. - 2011. - № 4 (13). - С. 205-210.

5. Leung E. Biloenteric fistula et laparoscopic cholecystectomy: rewiev of ten year's experience / E. Leung, P. Kumar // Surgeon. - 2010. - Vol. 8, № 2 - P. 67-70. 